\title{
The Buserelin Enigma; How Does Treatment with this GnRH Analogue Decrease Embryo Mortality?
}

\section{JR Newcombe ${ }^{1 *}$ and AR Peters ${ }^{2}$}

${ }^{1}$ Equine Fertility Clinic, Warren House Farm, West Midlands, UK

${ }^{2}$ Arpexas Limited, Hawkinge, Folkestone, Kent, UK

\begin{abstract}
The use of the $\mathrm{GnRH}$ analogue buserelin administered in mid dioestrus has been shown to increase early pregnancy rate, reduce embryo loss and increase litter size in several species. The mechanism by which this works is unclear and may differ between species. In cattle it is believed that buserelin, by reducing oestrogen concentrations, causes the development of endometrial oxytocin receptors to be delayed. Luteal oxytocin binds with these receptors to promote the formation and secretion of prostaglandin. Any delay in the release of PGF2 $\alpha$ would allow an underdeveloped embryo extra time to produce and release the maternal recognition of pregnancy signal, which might otherwise be lost following luteolysis. This may also be the mechanism in sheep and pigs although an increase in progesterone concentrations could also be important. However in the mare, following buserelin administration at 9 or 10 days after the detection of ovulation, pregnancy rates are already increased by 12-13 days compared with untreated controls, i.e. before the time of luteolysis, without any change in progesterone concentrations. In addition to an increased pregnancy rate, the twin embryo rate is also increased and subsequent embryo loss rate reduced. The possible mechanisms by which this may result in the mare are discussed.
\end{abstract}

Keywords: Embryo; Pregnancy; Embryo loss; Mare; Cow; Progesterone; GnRH; Buserelin

\section{Introduction}

Field studies in several domestic species have consistently shown that the administration of a single treatment with buserelin or other GnRH analogues in mid to late dioestrus, results in increases in pregnancy rate and/or litter size. Temporary support of luteostasis during the time of maternal recognition is believed to be the mechanism for this increase in cows. Treatment of dioestrous mares with buserelin has shown improvements in pregnancy rate of up to $10 \%$. However, because pregnancy diagnosis using ultrasound can be made in mares before the time of luteolysis, temporary luteostasis cannot be the mechanism in this species. This review explores and compares the relationships between progesterone, luteolysis and GnRH (buserelin) in the mare and the cow and suggests other possible avenues for future investigation.

\section{The Role Of Progesterone In Luteolysis In The Cow}

The maintenance of the corpus luteum (luteostasis; CL) in the cow is a balance between luteotrophic and luteolytic mechanisms. Luteolysis is caused by pulsatile release of PGF2 $\alpha$ from the endometrium which is driven by pituitary and/or luteal oxytocin [1]. Development of oxytocin receptors in the endometrium is dependent upon oestradiol-17 $\beta$ and progesterone stimulation [2] but these receptors may not be present until Day 16 or 17 [3]. Whilst the luteal phase of the cycle is effectively defined by the secretion of progesterone, any delay in rising oestradiol$17 \beta$ concentrations, delays the development of these receptors and thus delays luteolysis [4].

In the ruminant, secretion of interferon $\tau$ by the conceptus inhibits the synthesis of the luteolysin PGF2 $\alpha$ [5] and is therefore considered to be the signal for the maternal recognition of pregnancy (MRP). It is thought that much infertility in dairy cows is due to insufficient or delayed production of this anti-luteolytic signal from the conceptus with the consequent failure to block luteolysis [6]. Any delay in the release of PGF2 $\alpha$ may allow a slightly immature conceptus with delayed secretion of interferon $\tau$, to develop further, to a stage of maturity at which it can produce sufficient interferon to successfully block luteolysis. About $80 \%$ of embryo and foetal loss is thought to occur before 25 days [7] with the majority of this before Day 17 , partly due to failure of the antiluteolytic signal. Therefore embryo loss occurring at this time does not affect cycle length such that these cows return to oestrus at the normal interval of around 21 days.

There is uncertainty in the literature as to when progesterone profiles in pregnant and non-pregnant cows start to diverge. For example [8] milk progesterone profiles were similar up to about Day 12 but then started to fall in those not pregnant. However luteolysis per se is not initiated until Day 16 or 17. It has therefore been suggested that the CL is sensitive to low levels of PGF2 $\alpha$ as early as Day 11 or 12 [7]. However other studies [9] have shown that a single pulse of PGFM (metabolite of PGF2 $\alpha$ ) occurs before the start of luteolysis with only a transient effect upon peripheral progesterone concentrations, since this is followed by an LH pulse which restores progesterone to previous levels. Full luteolysis is initiated by a second PGFM pulse some 8 hours after the first, at about 17 days after ovulation [9]. From then on, luteolysis is essentially completed within 16-24 hours. The fall in progesterone after Day 11 is therefore probably not due to PGF2 $\alpha$ release but more likely a result of reduced LH secretion or loss of some other luteotrophic support. Conversely progesterone concentrations in pregnant cows are maintained due to elevated $\mathrm{LH}$ on which the CL becomes dependent in order to maintain the pregnancy. Up to $90 \%$ of well-managed, inseminated cows may have embryos at Day 16, but embryos were

${ }^{*}$ Corresponding author: JR Newcombe, Equine Fertility Clinic, Warren House Farm, West Midlands, UK, Tel: 01543 373033; E-mail: john@warrenhousevets.com

Received November 14, 2013; Accepted January 04, 2014; Published January 06, 2014

Citation: Newcombe JR, Peters AR (2014) The Buserelin Enigma; How Does Treatment with this GnRH Analogue Decrease Embryo Mortality? J Veterinar Sci Technol 5: 151. doi:10.4172/2157-7579.1000151

Copyright: ( 2014 Newcombe JR, et al. This is an open-access article distributed under the terms of the Creative Commons Attribution License, which permits unrestricted use, distribution, and reproduction in any medium, provided the original author and source are credited. 
found to be larger in cows which had a normal postovulatory rise in progesterone, while smaller under-developed embryos were found in those cows which had a slower rise in progesterone to sub-optimal peak levels [10-12]. Thus not only is progesterone essential to maintain the pregnancy in cows but adequate concentrations in early dioestrus, are necessary for optimal embryo development [13].

\section{Gnrh and Early Pregnancy in the Cow}

Treatment with GnRH between Day 11 and 13 after insemination appears to depress the luteolytic drive via reduced plasma oestradiol$17 \beta$ concentrations and the oestradiol:progesterone ratio $[14,15]$. Treatment with buserelin either induces ovulation, luteinisation or atresia of the dominant follicle depending on its stage of development [16,17]. It was reported [18] that buserelin given four times daily from Day 9 to 12, extended the cycle length by 6 days and increased progesterone concentrations. Treatment with either of two GnRH agonists, gonadorelin (Fertagyl) or buserelin (Receptal) from Day 3 to 17 , delayed luteolysis for up to 6 days in heifers challenged with $15 \mathrm{mg}$ of the PGF2 $\alpha$ agonist luprostiol on Day 13 [19]. Similarly in another study [20] where PGF2 $\alpha$ and GnRH were given simultaneously on Day 8 or Day 10 , luteolysis was delayed. Thus it appears that exogenous GnRH not only delays the endogenous luteolytic drive but can also protect against luteolysis caused by exogenous luteolysin.

Several reports suggest that a single injection of a GnRH agonist given to cows between Day 11 and Day 13 results in increased progesterone concentrations and increased pregnancy rates by about $10 \%$ [21-25], although two reports found no overall effect [26,27] or no effect on certain farms [25]. Buserelin $(10 \mu \mathrm{g})$ given on Day 12 to dairy cows, significantly improved pregnancy rates from 53\% to $65 \%$ at first service and from $53 \%$ to $59 \%$ at repeat services [28]. In one study [25] there was an average improvement in pregnancy rate of almost $10 \%$, from $50.6 \%$ to $60 \%$ at first service and a $13.2 \%$ improvement at second service after administration of $10 \mu \mathrm{g}$ buserelin 11 days after insemination on 19 farms. Surprisingly, improvements were seen in both herds with low and high overall pregnancy rates. In another study [22], improved pregnancy rates were reported at first service from $61 \%$ to $72 \%$ and from $70 \%$ to $85 \%$ at $2^{\text {nd }}$ service. Intravaginal progesterone and buserelin treatment on Day 11 [28] resulted in improved dairy cow pregnancy rates from $56 \%$ to $68 \%$. Some authors have reported the presence of accessory CLs after buserelin treatment on Day 11 or 12 [29] whereas others did not [21]. In a meta-analysis of all available field trial data at that time, almost 11,000 cows in 19 trials [30], there was a high degree of variance in the effect of GnRH given to cows between 11 and 14 days after insemination. However in those studies where the experimental parameters were similar $(n=6 ; 2,500$ cows), the increase in pregnancy rate was as much as $33 \%[30,31]$.

Blood samples were taken between Day 14 and 17 after service [32] and the third of lactating beef cows with the highest oestradiol$17 \beta$ concentrations (mean $3.1 \mathrm{pg} / \mathrm{ml}$ ) had a pregnancy rate of only $42 \%$ whereas those with concentrations in the middle and lower thirds $(2.1$ and $1.6 \mathrm{pg} / \mathrm{ml}$ ) had pregnancy rates of $60 \%$ and $77 \%$ respectively. Clearly high oestradiol- $17 \beta$ concentrations at this stage were negatively associated with pregnancy rate. During the luteal phase, oestradiol-17 $\beta$ is produced by secondary and tertiary waves of follicle development and is associated with an increase in the concentration of oxytocin receptors in the endometrium, as part of the PGF2 $\alpha$ luteolytic cascade [33]. In another study [15] there was no effect on plasma progesterone concentrations after $10 \mu \mathrm{g}$ buserelin treatment on Day 12. However there was a significant decline in oestradiol-17 $\beta$ in pregnant cows compared with both non-pregnant treated cows and controls, similarly in non-inseminated cows when treated on Days 11 and 13. Mann and Picton (33) also found that oestradiol-17 $\beta$ was significantly lower on Day 13-16 and PGFM lower on Days 14-16 in Day 12 buserelin treated cows, consistent with an anti-luteolytic mechanism operating.

\section{Gnrh and Pregnancy in Sheep and Pigs}

Buserelin has also been used to improve fertility in sheep [34]. These New Zealand authors injected ewes and ewe lambs on either Day $10,11,12$ or 13 after mating and showed improved pregnancy rates particularly in those injected on Day 12. This approach was repeated [35] under Welsh conditions in which there was a marginal but nonsignificant increase in non-return rate (controls: $76 \%$ versus treated: $83 \%$ ) and litter size (1.51 versus 1.77) in 3 of 4 flocks. However, there was a significant increase in the twinning rate (20\% versus $40 \%)$ and litter size (1.44 versus 1.68) in one flock of ewe lambs. A group of animals was slaughtered on Day 31 of pregnancy revealing a higher ovulation rate in treated ewes, suggesting that any beneficial effects of this treatment might be due to increased progesterone from accessory CL. In a further study to examine the possible mechanism [36], ewes were injected with buserelin 12 days after mating and plasma concentrations of plasma progesterone and oestradiol-17 $\beta$ measured. The animals were slaughtered $48 \mathrm{~h}$ after treatment. The ovulation rate was significantly higher in treated ewes (2.76 versus 1.87$)$ and 41 of the $113 \mathrm{CL}$ observed in the GnRH-treated group, had formed during the previous $48 \mathrm{~h}$ compared with $2 / 71$ of the controls. Plasma progesterone concentrations were higher and oestradiol- $17 \beta$ concentrations lower in the treated ewes. Thus this picture was reasonably consistent with that in cattle and it is thought likely that a similar mechanism was operating [36].

The effect of buserelin $(8 \mu \mathrm{g})$ on the fertility of outdoor sows has also been examined [37]. A total of 1231 mixed parity sows from five farms were randomly assigned to either buserelin treatment within $24 \mathrm{~h}$ of service, or on Day 11 or 12 after service, or were left untreated as controls. There was no significant effect on farrowing rates or on overall total litter size. However, there was a significant increase in the number of pigs born alive, averaging approximately 0.5 pigs per litter, in both buserelin treated groups. This was an interesting and unexpected result and was difficult to reconcile with the lack of effect on overall litter size. Any difference between overall litter size and live litter size is due to foetal death either at or immediately after parturition. It was apparent that neither treatment with buserelin had any immediate effect on embryo survival. Therefore it was tentatively proposed [37] that the buserelin treatment resulted in an improved quality or viability of the embryos and subsequent foetuses, by improving the synchrony between service and ovulation (Day 1) or possibly by increasing progesterone concentrations (Day 11 or 12). To our knowledge there has been no further work to confirm, refute or extend this work in pigs.

\section{Luteolysis and the Role of Progesterone in the Mare}

Luteolysis in non-pregnant mares is the result of a positive feedback between pituitary [38] and/or endometrial oxytocin and PGF2 $\alpha$ [39]. Exogenous PGF $2 \alpha$ causes luteolysis in both pregnant and non-pregnant mares. Exogenous oxytocin results in PGF2 $\alpha$ release but only in nonpregnant mares [40]. The significant increase in oxytocin receptor site concentration which occurs between Days 12 and 14 does not occur in pregnant mares [41]. While the mechanisms for recognition of pregnancy are known in ruminants and the pig, in the mare, it does not now appear to be due to the release of interferons, oestrogen or other steroids by the embryo [42]. However one study [43] reported that the 
equine embryo expressed genes for interferon-delta but not until after Day 16 which is too late to be responsible for pregnancy recognition.

The embryo does appear to release an anti-luteolytic signal to most if not all parts of the endometrial surface during its migratory phase, which can inhibit the synthesis and/or release of PGF2 $\alpha$ following oxytocin challenge. Induction of Cox-2 expression in the surface epithelial cells in late dioestrus of cyclic mares results in the pulsatile release of PGF2 $\alpha$ which is blocked by the presence of a conceptus [44]. It has been shown [45] that prostaglandin synthase 2 is the target for the anti-luteolytic signal with PGF2 $\alpha$ concentrations being either increased or reduced in endometrial explants, by oxytocin or conceptus secretions respectively. By restriction of the embryo and its secretions to one horn and body of the uterus, sufficient PGF2 $\alpha$ was released from the other horn to effect luteolysis [46]. However the role of the embryonic secretions in inhibiting luteolysis or promoting luteostasis, has been brought into question by a recent study [47] where Day 10 embryos were successfully transferred into Day 3 uteri. By the time that MRP was needed to suppress luteolysis at Days 10-14, the embryos were already 17-21 days old and had ceased intrauterine movement several days earlier. Even if, at this age, the embryos were still capable of producing a MRP signal, its distribution throughout the lumen was apparently unnecessary to suppress luteolysis.

In further work [48], it was found that luteolysis in non-pregnant mares could be blocked by the intrauterine administration of both peanut and coconut oils but not by mineral oil. It had been shown many years previously [49] that intrauterine infusion of sodium benzyl penicillin during dioestrus caused luteal persistence in $46 \%$ of 13 pony mares. Inanimate objects have also been shown to cause luteostasis. Glass balls inserted at ovulation extended luteal function in 39\% of mares [50] although other authors [51,52] failed to find that this caused any modification of behaviour or luteal function in pony mares. Waterfilled plastic balls inserted at oestrus [53], prevented luteolysis in $75 \%$ of 12 treated mares despite the fact that the balls remained in one location and did not migrate through the uterus.

The above reports suggest that neither an embryo-produced MRP endocrine signal nor intrauterine migration is necessary to promote luteostasis. It is possible therefore that luteostasis is not necessarily the result of an endocrinological signal, but that it possibly results from the physical interaction between the endometrium and the early embryo, marble, plastic ball or oil (S. Wilsher, personal communication).

Luteal persistence in non-pregnant cows is unusual although it is associated (24\%) with higher milk yielding post-partum cows [51]. It is relatively common in horse mares although not so in native ponies [W. E. Allen, personal communication]. The CL of the mare therefore appears to be comparatively less susceptible to luteolysis, or alternatively luteolysis is more susceptible to disruption. The equine $\mathrm{CL}$ is however more sensitive to exogenous prostaglandin than the cow [54]. Doses as small as $12.5 \mu \mathrm{g}$ of dl-cloprostenol [55] and $3.75 \mu \mathrm{g}$ d-cloprostenol (J. Newcombe, unpublished data) have been shown to be luteolytic when the CL is fully mature. In contrast however, it can be rendered insensitive by repeated 8 hourly treatment with exogenous d-cloprostenol (Genestran) given during the first few days of dioestrus (Newcombe and Cuervo-Arango, Poster ISER 2014)

Although early pregnancy loss is a major cause of infertility in mares, losses due to failure of the anti-luteolytic signal and consequent luteolysis are infrequent [56]. While some embryos are significantly small for age by about 2 days growth $(8 \mathrm{~mm})$ or more, only those which are the most retarded fail to block luteolysis [57]. Average reported embryo loss rates between Days 11 to 15 and 40 to 50 are $7.7 \%$ [56] and are highest between the first ultrasonic pregnancy examination at Day 12 to 14 and the next examination at around 21 days after service. Loss rates in the following weeks are much lower. Unlike the cow where luteal survival is dependent on luteotrophic support from the conceptus, it is uncommon for embryo failure to be either caused by, or to be followed by luteolysis [56,58]. Usually the CL will persist for its normal lifespan of about 60 to 110 days in the absence of a viable embryo $[59,60]$.

Most reports suggest that pregnancy rates at Days 12 to 14 in the mare are around $60-65 \%$ and yet fertilisation rates are considered to be much higher; at least $85 \%$ for older mares and nearer $95 \%$ for young mares [61]. Thus a considerable degree of embryo loss, in the order of $25 \%$ to $35 \%$, must occur between fertilisation and the first ultrasonic examination for pregnancy between Day 12 and 14 .

There is little or no evidence that progesterone supplementation during the first two weeks of dioestrus results in increased pregnancy rates in the mare. In fact there is much evidence that the early equine conceptus can survive and develop at a normal rate for several days during low [62] or even sub-luteal plasma progesterone concentrations. When exogenous PGF2 $\alpha$ is given during early pregnancy resulting in luteolysis, the conceptus continues to develop for several days at a normal rate until it suddenly disappears. Pregnancy failure may be due to evacuation through the cervix as the mare comes into oestrus, rather than embryonic death. Later embryos, following PGF2 $\alpha$ administration, may be seen still with a heartbeat even though the conceptus has become dislocated by endometrial oedema and fluid secretions. Embryos in 10 pregnant mares, given a single dose of cloprostenol between Day 8 and 26, survived and developed normally for between 2 and 8 days after treatment (mean 4.7 days; J Newcombe, unpublished data). At the next examination after the last one in which the viable embryo was still present ( 2 to 5 days later), the vesicle had either disappeared or the embryo appeared dead.

Two cases of pregnant mares which returned to oestrus yet retained their pregnancy following a spontaneous ovulation, have been reported $[63,64]$ and a third unreported (J Newcombe, unpublished data). Early pregnancies with clinical evidence of spontaneous luteal regression can be saved by progesterone supplementation [65]. Inevitably a spontaneous ovulation occurs at about Day 21 or 22 after which progesterone supplementation can be withdrawn (J Newcombe, unpublished data). It has even been suggested [66] that only a relatively low threshold progesterone level is necessary to maintain pregnancy. Indeed it has been confirmed by the present author that pregnancy can survive low progesterone concentrations from soon after ovulation. Fourteen inseminated mares were treated with multiple luteolytic doses $(37.5 \mu \mathrm{g})$ of d-cloprostenol every 8 hours starting as early as 28 hours post ovulation and continued to as late as 124 hours. NinEight (57\%) were diagnosed pregnant at 12 to 13 days and were still pregnant at 20 days although several had ovulated without any clinical evidence of oestrus (Newcombe and Cuervo-Arango, Poster ISER 2014).

\section{Embryo Loss in the Mare}

There is little experimental evidence as to when embryo losses occur before the time of the first ultrasonic pregnancy detection which is usually between Day 11 and 14. Any evidence has to be based on the percentage of embryos flushed from either the uterine tubes or the lumen on different days after ovulation. In one study [67] significantly fewer embryos per ovulation were recovered following unilateral twin ovulations versus bilateral ovulations ( $54 \%$ v. $66 \%$ ). In a large field study, less than half the mares pregnant after multiple ovulations were found 
to have multiple pregnancies at Day 13 to 14 [68]. In another study [57], the twin pregnancy rate following bilateral ovulations (41\%) was significantly higher than that from unilateral twin ovulations $(27.5 \%)$ while the total pregnancy rate was $67.5 \% \mathrm{v}$. $60 \%$, following bilateral v. unilateral respectively. This suggests that some embryo failure may be at tubal level (assuming both embryos enter the oviduct and are fertilised) since once free and mobile in the uterus, the side of origin should have no influence. Additionally, more twin pregnancies were found to have one embryo that was small for age from unilateral ovulations (31\%) than from bilateral ovulations (22\%) [57]. Small for age (SFA) embryos are more likely to fail spontaneously [57]. Most single SFA embryonic vesicles which are not ultrasonically detectable at 13 or 14 days after ovulation will fail subsequently [57], whereas all vesicles detected at 11 days after ovulation progressed normally to at least the foetal stage [69]. When the embryo proper was first detected at 17 or 18 days post ovulation, all 30 pregnancies progressed to the foetal stage [70]. Even in the 278 pregnancies in which the embryo proper was first detected at 19 days after ovulation, the embryo loss rate was only $1.8 \%$. In that study the embryo proper failed to be detected in only 36 (9.6\%) of 374 pregnancies by 21 to 23 days after ovulation, but of those 36 cases, 16 (44.4\%) had failed by 40 days [70].

Day 4 embryos transferred from fertile single ovulating donors had a survival rate of $58 \%$ in normal recipients [61]. However the survival rates of transferred embryos from subfertile single ovulators, from fertile multiple ovulators or from subfertile multiple ovulating donors were significantly lower, at $33 \%, 28 \%$ and $0 \%$ respectively. Even if only $42 \%$ (100-58\%) of embryos which might not have failed otherwise, had been lost due to transfer, at least $25 \%$ of embryos (58\% minus $33 \%$ ) from subfertile single ovulators must have failed between Day 4 and about Day 14. Even more embryos must have failed from both the fertile and the subfertile multiple ovulators. Only $57 \%$ of Day 7 embryos per ovulation, in multiple ovulated mares were flushed successfully, compared with $64 \%$ of embryos from single ovulations [71]. In another study [72] the same number of embryos (71\%), were flushed on Day 7 as on Day 11 from two groups of 14 single ovulating mares, suggesting minimal losses at this stage. However, from 63 multiple ovulators, the same authors [67] flushed a similar (67\%) percentage of embryos per ovulation on Day 7 but only $42 \%$ on Day 11, indicating a major loss (37\%) of embryos from multiple ovulations between Days 7 and 10 . The percentage of SFA embryos recovered from these multiple ovulating mares also rose from $1.5 \%$ on Day 7 to $64 \%$ on Day 11 , suggesting that in addition to those embryos already lost by Day 11, more than half of the remainder were retarded. A further study [73] reported that of the $69 \%$ and $43 \%$ embryos flushed on Days 7 or 8 from normal and subfertile mares respectively, the percentage of abnormal embryos was $7 \%$ and $56 \%$ respectively indicating that embryo loss in subfertile mares occurs both before and after Day $7 / 8$.

\section{The Role of Gnrh (Buserelin) in Pregnancy in the Mare}

GnRH analogues were first developed for the induction of ovulation. When first tested in mares [74] buserelin was found to have no effect on mares in deep anoestrus or on those with regressing follicles, whereas two thirds of mares in the transitional breeding season, ovulated, and a satisfactory $97 \%$ of cyclic mares with a mature follicle ovulated within 48 hours following a large single injection of 1 to $4 \mathrm{mg}$. Another report found that a less satisfactory $89 \%$ of mares ovulated within 48 hours following a single injection of $6.3 \mathrm{mg}$ buserelin [75]. Subsequently a short term controlled release implant of deslorelin (Ovuplant) has become widely used for the induction of ovulation in transitional mares.
The effects of buserelin given in mid-dioestrus on pregnancy rates have been studied in thoroughbred mares in field trials [76,77]. In a series of trials, $40 \mu \mathrm{g}$ was given by a single subcutaneous injection to mares on Day 9, 10, 11 or 12 (initially) then later, either $20 \mu \mathrm{g}$ or $40 \mu \mathrm{g}$ buserelin was given either on Day 10 or on Day 11. Later field trials were done with either $20 \mu \mathrm{g}$ or $10 \mu \mathrm{g}$. Improvements in Day 13-15 pregnancy rates after first service were found in every trial when mares were treated on Day 10 or 11. From 1994 to 2004, the margins of improvement in pregnancy rates over untreated controls in 14 trials were $6.0 \%, 14.2 \%$, $7.3 \%, 12.2 \%, 12.5 \%, 2.2 \%, 16.5 \%, 2.4 \%, 7.3 \%, 4.2 \%, 9.3 \%, 9.1 \%$ and $2.5 \%$ (latter two both in 2003) and $2.2 \%$ in $2004(\mathrm{P}<0.0001$ by metaanalysis [78]). From 2008 to 2010 using either 20 or $10 \mu \mathrm{g}$ buserelin, improvements were $2.2 \%, 16.5 \%$ and $13.9 \%$ respectively, an average of $7.6 \%$ [78]; J. Newcombe unpublished data]. A $2.86 \%$ increase in the number of mares with multiple embryos was also found in buserelin treated mares $17.32 \%(n=2540)$ v. $14.46 \%(n=1452)$. This represented a significant $(\mathrm{P}<0.001)$ increase of $19.8 \%$ in the percentage of mares with multiple embryos. The effect of buserelin even extended beyond the time of first pregnancy examination. Embryo loss from that time and up to 40 days was reduced from $8.22 \%$ in 1314 pregnancies to $6.06 \%$ of 2427 pregnancies $(\mathrm{P}=0.014)$. In those mares which did not conceive at the first cycle, treatment in the second or subsequent cycles improved pregnancy rates regardless of whether or not they had been treated with buserelin in the first or previous cycle (J. Newcombe, unpublished data)

In other work [79], $40 \mu \mathrm{g}$ buserelin was administered on Day 10 to half of 171 warm blood mares inseminated with either fresh or frozen/thawed semen. The pregnancy rate in treated mares was $46 \%$ compared with $36.4 \%$ for untreated mares $(\mathrm{P}=0.22)$. Although progesterone concentrations were unaffected, the authors found that LH concentrations were significantly elevated. Others [80] giving 40 $\mu \mathrm{g}$ buserelin on Day 10 also found no evidence of raised progesterone concentration, secondary ovulations or prolonged luteal life. In another study [81] mares were challenged on Day 12 with oxytocin after giving $40 \mu \mathrm{g}$ buserelin to mares on Day 10 . There was no difference between pregnant and non-pregnant treated mares in their PGFM response. Buserelin was therefore unable to suppress luteolysis in the nonpregnant mare.

The effect of $40 \mu \mathrm{g}$ buserelin given 10 days after AI was investigated in a group of subfertile mares inseminated with either fresh or frozen/ thawed semen [82]. Half the mares were treated and half remained as untreated controls. Pregnancy rates over 136 untreated cycles averaged $34.5 \%$, with $41.6 \%$ for fresh and $31.2 \%$ for frozen semen respectively. Pregnancy rates in the same mares when treated with buserelin averaged $44.8 \%$, with $48.4 \%$ for fresh and $41.8 \%$ for frozen semen. The $10.3 \%$ overall increase in the pregnancy rate in treated cycles meant an actual increase of nearly $30 \%$ in the total number of pregnancies.

It has been shown [83] that a GnRH antagonist given on Day 8 could have an adverse effect on pregnancy apparently by causing a sharp drop in progesterone concentrations while in three other reports, a GnRH agonist did not cause any P4 elevation [80-82].

\section{Conclusions}

There is therefore much clinical evidence that the administration of a single subcutaneous injection of 40 or $20 \mu \mathrm{g}$ of aqueous buserelin to mares, 9 to 10 days after the detection of ovulation produces a highly significant improvement in pregnancy rate [77], including an increase in embryo numbers in multiple ovulating mares. This is evident by the time of early ultrasonic detection of the embryonic vesicle at 12 to 13 days after ovulation, before the time of luteolysis and only 2 to 
4 days after treatment. This improvement in pregnancy rate has been demonstrated by various other studies in horses, cows, sheep and pigs, while in the latter two species, litter size may also be enhanced. Improvements in both pregnancy rate and litter size suggest a reduction in embryo loss between the time of buserelin administration and the time of pregnancy detection. Although there is no ultrasonic evidence that pregnancy rates are already elevated before the time of luteolysis, the mechanism by which post-luteolysis pregnancy rate is improved in dairy cows, is reasonably assumed to be by delaying the endogenous luteolytic drive; embryos with delayed development can gain sufficient maturity to block luteolysis. Increased progesterone concentrations may also boost conceptus development. Blocking luteolysis may also be the mechanism in pigs and sheep. However it would not account for any increase in litter size in those species since luteolysis is all or nothing. It is possible that there is differential sensitivity between embryos to progesterone concentrations.

Buserelin may act in two ways by both delaying luteolysis in pregnant ruminants (although it does not in either the horse or in the non-pregnant ruminant) whilst also reducing embryo loss in multiple pregnancies. Mechanisms for multiple embryo reduction occur in many species most notably the pig. The South American rodent, the Plains Viscacha ovulates 400-800 oocytes of which just 8 to 10 are fertilised, but normally produces only one or two young [84]. One might speculate that during evolution, from the tiny rodent-like mammals of the cretaceous period, which had evolved to produce large litters in order to counteract the effects of predation, (like most small modern rodents), to the large monotocous mammals of today like the elephant, the bovidae and the equidae, that a mechanism for embryo reduction, has been conserved in modern (normally) monovular species. If so, then it could be responsible for twin pregnancy reduction and even some reduction of single embryos.

High progesterone concentrations may well have a role in increased embryo survival in farm animals and other species. However in the mare there is neither evidence of any effect of buserelin on progesterone concentrations nor indeed any evidence that pregnancy is dependent on continuously elevated concentrations of progesterone. On the contrary, a pregnancy can survive, and develop at the normal rate as judged by growth rate of the early embryonic vesicle, in the presence of continuous prostaglandin suppressed progesterone concentrations, or even for short periods during non-luteal $(<1 \mathrm{ng} / \mathrm{ml})$ progesterone concentrations with the mare in oestrus $[64,83,85]$.

If a mechanism to delay the luteolytic drive were to exist in the mare then the increase in pregnancy rate would not become apparent until after the time of luteolysis (after Day 15 or 16). The various studies show that the increase in mares occurs before the time of luteolysis. In any case, spontaneous luteolysis in the pregnant mare is at best unusual whilst embryonic loss which occurs after about Day 12 is rarely followed by luteolysis [58]. Unlike the cow, the CL persists after embryonic death since it is not dependent on embryonic support.

So if the embryo support mechanism induced by buserelin treatment in the mare is independent of CL function or progesterone secretion per se, what other factors could be involved? That exogenous GnRH stimulates LH and FSH secretion both during oestrus and dioestrus is well established. Is it possible that GnRH stimulated $\mathrm{LH}$ and FSH release during dioestrus may have some effect independent of the ovary?

The role of oestradiol-17 $\beta$ in early equine pregnancy is unclear but as in the cow, buserelin may well influence oestradiol-17 $\beta$ secretion.
Reduction of oestradiol-17 $\beta$ concentrations is important in the delayed development of oxytocin receptors and luteostasis in the cow. Exogenous oestradiol-17 $\beta$ significantly reduced progesterone concentration but did not affect embryonic development [62]. It has been argued [86] that increased follicular oestradiol-17 $\beta$ production is not necessary for luteolysis in mares. Since this steroid has not been investigated in buserelin treated mares, it is possible that its influence is on either the endometrium or directly on the embryo. Even if there is an interferon produced at this time, either by the embryo or by the endometrium, how could this be influenced directly or indirectly by $\mathrm{GnRH}$ ?

GnRH analogues have been shown to have various sites of action other than the pituitary, most notably on the urinary tract of bitches [87], while GnRH receptors have been recognised in various other tissues [88] including the placenta [89]. Binding sites for LH / hCG are found in the uterus of several species with maximum expression in the luteal phase [90]. Maximum expression of the GnRH receptor in the human uterus also occurs during the luteal phase [90]. That author in reviewing the actions of gonadotrophins on the uterus, concluded that "The presence of gonadotrophin and GnRH receptors with a dynamic pattern in the endometrium, myometrium, oviduct and cervix of different species provides evidence that gonadotrophins and $\mathrm{GnRH}$ play a substantial role as molecular autocrine-paracrine regulators of the oestrous cycle and implantation" [90]. The author is suggesting that $\mathrm{GnRH}$ could have a direct role at the level of the reproductive tract that does not involve the ovary. Therefore there could be a direct effect of exogenous $\mathrm{GnRH}$ (buserelin) on the relationship between the embryo and the endometrium. Irrespective of the mechanism, it is evident that buserelin acts independently of the CL in the mare, by limiting the effect of any embryo reduction process operating between Days 9 to 10 and 13 to 14 of pregnancy.

\section{References}

1. Kim S, Choi Y, Spencer TE, Bazer FW (2003) Effects of the estrous cycle, pregnancy and interferon tau on expression of cyclooxygenase two (COX-2) in ovine endometrium. Reprod Biol Endocrinol 1: 58.

2. Thatcher WW, McMillan KL, Hanson PJ, Drost M (1989) Concepts for regulation of corpus luteum function by the conceptus and ovarian follicles to improve fertility. Theriogenology 31: 149-164.

3. Mann GE, Lamming GE (1994) Use of repeated biopsies to monitor endometrial oxytocin receptors in the cow. Vet Rec 135: 403-405.

4. MacMillan KL, Thatcher WW, Drost M (1989) Proc 49th Animal Conference of Newzeland Society.

5. Thatcher WW, Meyer MD, Danet-Desnoyers G (1995) Maternal recognition of pregnancy. J Reprod Fertil Suppl 49: 15-28.

6. Peters, A. R. (1996) Embryo mortality in the cow animal. Breeding Abstracts 64: $587-598$

7. Lamming GE, Darwash AO, Back HL (1989) Corpus luteum function in dairy cows and embryo mortality. J Reprod Fertil Suppl 37: 245-252.

8. Bulman DC, Lamming GE (1978) Milk progesterone levels in relation to conception, repeat breeding and factors influencing acyclicity in dairy cows. J Reprod Fertil 54: 447-458.

9. Ginther OJ, Shrestha HK, Fuenzalida MJ, Shahiduzzaman AK, Hannan MA, et al. (2010) Intrapulse temporality between pulses of a metabolite of prostaglandin F2alpha and circulating concentrations of progesterone before during, and after spontaneous luteolysis in heifers. Theriogenology 74: 11791186.

10. Mann GE (1996) The relationship between the cow and the embryo during early pregnancy. Proceedings of Nottingham Cattle Fertility Conference.

11. Mann GE, Lamming GE, Robinson RS, Wathes DC (1999) The regulation of interferon-tau production and uterine hormone receptors during early pregnancy. J Reprod Fertil Suppl 54: 317-328. 
Citation: Newcombe JR, Peters AR (2014) The Buserelin Enigma; How Does Treatment with this GnRH Analogue Decrease Embryo Mortality? J Veterinar Sci Technol 5: 151. doi:10.4172/2157-7579.1000151

12. Mann GE, Lamming GE (1999) The influence of progesterone during early pregnancy in cattle. Reprod Dom Anim 34: 269-274.

13. Inskeep EK (2004) Preovulatory, postovulatory, and postmaternal recognition effects of concentrations of progesterone on embryonic survival in the cow. J Anim Sci 82 E-Suppl: E24-39.

14. Mann GE, Lamming GE (1995) Effects of treatment with buserelin on plasma concentrations of oestradiol and progesterone and cycle length in the cow. $\mathrm{Br}$ Vet J 151: 427-432.

15. Mann GE, Lamming GE (1995) Plasma oestradiol-17ß and progesterone during early pregnancy in the cow and the effects of treatment with buserelin. Anim. Reprod. Sci. 37: 121-131.

16. Peters AR, Drew SB, Mann GE, Lamming GE, Beck NF (1992) Experimental and practical approaches to the establishment and maintenance of pregnancy. J Physiol Pharmacol 43: 143-152.

17. Twagiramungu H, Guilbault LA, Proulx JG, Dufour JJ (1994) Influence of corpus luteum and induced ovulation on ovarian follicular dynamics in postpartum cyclic cows treated with buserelin and cloprostenol. J Anim Sci 72: 1796-1805.

18. Milvae RA, Murphy BD, Hansel W (1984) Prolongation of the bovine estrous cycle with a gonadotropin-releasing hormone analog. Biol Reprod 31: 664-670.

19. Birnie LM, Broadbent PJ, Hutchinson JS (1997) Failure of prostaglandin F2 alpha analogue to induce luteolysis in $\mathrm{GnRH}$ agonist treated heifers. Vet Rec 140: 315.

20. Stevens RD, Seguin BE, Momont HW (1993) Simultaneous injection of PGF2alpha and GnRH into diestrous dairy cows delays return to estrus. Theriogenology 39: 373-380.

21. MacMillan KL, Day AM, Taufa VK, Gibbs M, Pearce MG (1985) Effects of an agonist of gonadotrophin releasing hormone in cattle. I. Hormone concentrations and oestrous cycle lengths. Anim. Reprod. Sci. 8: 203-212.

22. MacMillan KL, Taufa VK, Day AM (1986) Effects of an agonist of gonadotrophin releasing hormone (buserelin) in cattle. II. Pregnancy rates after a postinsemination during metoestrus. Anim. Reprod. Sci 11: 1-10.

23. Drew SB, Peters AR (1994) Effect of buserelin on pregnancy rates in dairy cows. Vet Rec 134: 267-269.

24. Lajili H, Humblot P, Thibier M (1991) Effect of PG F2 alpha treatment on conception rates of dairy cows treated with a GnRH agonist 12 to 14 days after Artificial Insemination. Theriogenology 36: 335-347.

25. Sheldon IM, Dobson H (1993) Effects of gonadotrophin releasing hormone administered 11 days after insemination on the pregnancy rates of cattle to the first and later services. Vet Rec 133: 160-163.

26. Jubb TF, Abhayaratne D, Malmo J, Anderson GA (1990) Failure of an intramuscular injection of an analogue of gonadotrophin-releasing hormone 11 to 13 days after insemination to increase pregnancy rates in dairy cattle. Australian Vet. J 67: 359-361.

27. Ryan DP, Snijders S, Condon T, Grealy M, Sreenan JM, et al. (1994) Endocrine and ovarian responses and pregnancy rates in dairy cows following the administration of a gonadotrophin releasing hormone analog at the time of artificial insemination or at mid-cycle post insemination. Anim. Reprod. Sci. 34: 179-191.

28. Lynch PR, Macmillan KL, Taufa VK (1999) Treating cattle with progesterone as well as a GnRH analogue affects oestrous cycle length and fertility. Anim Reprod Sci 56: 189-200.

29. Harvey MJ, Renton JP, Salaheddine M, Robertson L (1994) Ovarian and clinica response of cattle to buserelin. Vet Rec 134: 168-171.

30. Peters AR, Martinez TA, Cook AJ (2000) A meta-analysis of studies of the effect of $\mathrm{GnRH} 11-14$ days after insemination on pregnancy rates in cattle. Theriogenology 54: 1317-1326.

31. Peters AR (2005) Veterinary clinical application of GnRH--questions of efficacy. Anim Reprod Sci 88: 155-167.

32. Pritchard JY, Schrick FN, Inskeep EK (1994) Relationship of pregnancy rate to peripheral concentrations of progesterone and estradiol in beef cows. Theriogenology 42: 247-259.

33. Mann GE, Picton H (1995) Ovarian and uterine effects of a single buserelin injection on Day 12 of the oestrous cycle in the cow. J. Reprod. Fert. Abstract series 5: 61-65.
34. MacMillan WH, Knight TW, MacMillan KL (1986) Effects of gonadotrophin releasing hormone (buserelin) on sheep fertility. Proc. NZ Soc. Anim. Prod. 47: 161-163.

35. Beck NFG, Peters AR, Williams SP (1994) The effect of the GnRH analogue (buserelin) treatment on day 12 post mating on the reproductive performance in ewes. Anim. Prod. 58: 243-247.

36. Beck NFG, Jones M, Davies B, Mann GE, Peters AR (1996). The effect of $\mathrm{GnRH}$ analogue (buserelin) treatment on day 12 post mating on ovarian structures and plasma progesterone and oestradiol-17ß concentration in ewes. Anim. Sci. 63: 407-412.

37. Peters AR, Dwyer L, Canham PA, Mackinnon JD (2000) Effect of gonadotrophinreleasing hormone on the fertility of sows kept outdoors. Vet Rec 147: 649-652.

38. Vanderwall DK, Silvia WJ, Fitzgerald BP (1998) Concentrations of oxytocin in the intercavernous sinus of mares during luteolysis: temporal relationship with concentrations of 13,14-dihydro-15-keto-prostaglandin F2 alpha. J Reprod Fertil 112: 337-346.

39. Stout TA, Allen WR (2002) Prostaglandin $E(2)$ and $F(2$ alpha) production by equine conceptuses and concentrations in conceptus fluids and uterine flushings recovered from early pregnant and dioestrous mares. Reproduction 123: $261-268$.

40. Goff AK, Pontbriand D, Sirois J (1987) Oxytocin stimulation of plasma 15-keto13,14-dihydro prostaglandin F-2 alpha during the oestrous cycle and early pregnancy in the mare. J Reprod Fertil Suppl 35: 253-260.

41. Starbuck GR, Stout TA, Lamming GE, Allen WR, Flint AP (1998) Endometria oxytocin receptor and uterine prostaglandin secretion in mares during the oestrous cycle and early pregnancy. J Reprod Fertil 113: 173-179.

42. Baker CB, Adams MH, McDowell KJ (1991) Lack of expression of alpha or omega interferons by the horse conceptus. J Reprod Fertil Suppl 44: 439-443.

43. Cochet M, Vaiman D, Lefèvre $F$ (2009) Novel interferon delta genes in mammals: cloning of one gene from the sheep, two genes expressed by the horse conceptus and discovery of related sequences in several taxa by genomic database screening. Gene 433: 88-99.

44. Ginther OJ, First NL (1971) Maintenance of the corpus luteum in hysterectomized mares. Am J Vet Res 32: 1687-1691.

45. Ealy AD, Eroh ML, Sharp DC 3rd (2010) Prostaglandin H synthase Type 2 is differentially expressed in endometrium based on pregnancy status in pony mares and responds to oxytocin and conceptus secretions in explant culture. Anim Reprod Sci 117: 99-105.

46. Boerboom D, Brown KA, Vaillancourt D, Poitras P, Goff AK, et al. (2004) Expression of key prostaglandin synthases in equine endometrium during late diestrus and early pregnancy. Biol Reprod 70: 391-399.

47. Wilsher S, Allen WR (2009) Uterine influences on embryogenesis and early placentation in the horse revealed by transfer of day 10 embryos to day 3 recipient mares. Reproduction 137: 583-593.

48. Wilsher S, Allen WR (2011) Intrauterine administration of plant oils inhibits luteolysis in the mare. Equine Vet J 43: 99-105.

49. Allen WE (1981) Effect of intrauterine infusion of penicillin solution on lutea function in pony mares. Vet Rec 109: 216-217.

50. Nie GJ, Johnson KE, Braden TD, Wenzel GW (2003) Use of intra-uterine glass ball protocol to extend luteal function in mares. J. Equine vet. Sci. 23: 266-273

51. Kafi M, Mirzaei A, Tamadon A, Saeb M (2012) Factors affecting the occurrence of postpartum prolonged luteal activity in clinically healthy high-producing dairy cows. Theriogenology 77: 421-429.

52. Argo CM, Turnbull EB (2010) The effect of intra-uterine devices on the reproductive physiology and behaviour of pony mares. Vet J 186: 39-46.

53. Rivera Del Alamo MM, Reilas T, Kindahl H, Katila T (2008) Mechanisms behind intrauterine device-induced luteal persistence in mares. Anim Reprod Sci 107 94-106.

54. Douglas RH, Ginther OJ (1975) Route of prostaglandin F2alpha injection and luteolysis in mares (38519). Proc Soc Exp Biol Med 148: 263-269.

55. Newcombe JR, Jochle W, Cuervo-Arango J (2008) Effect of dose of cloprosteno on the interval to ovulation in the dioestrous mare: A retrospective study. J. Equine vet. Sci. 28: 532-539. 
Citation: Newcombe JR, Peters AR (2014) The Buserelin Enigma; How Does Treatment with this GnRH Analogue Decrease Embryo Mortality? J Veterinar Sci Technol 5: 151. doi:10.4172/2157-7579.1000151

56. Vanderwall DK, Newcombe JR (2007) In: Current Therapy in Equine Reproduction. Eds. Samper, Pycock \& McKinnon, Sanders Elsevier.

57. Newcombe JR (2004) The relationship between the number, diameter and survival of early embryonic vesicles. Pferdeheilkunde 20: 214-220.

58. Irvine $\mathrm{CH}$, Sutton P, Turner JE, Mennick PE (1990) Changes in plasma progesterone concentrations from days 17 to 42 of gestation in mares maintaining or losing pregnancy. Equine Vet J 22: 104-106.

59. Ginther OJ (1990) Prolonged luteal activity in mares--a semantic quagmire Equine Vet J 22: 152-156.

60. Lefranc AC, Allen WR (2004) Nonpharmacological suppression of oestrus in the mare. Equine Vet J 36: 183-185.

61. Ball BA, Little TV, Weber JA, Woods GL (1989) Survival of day-4 embryos from young, normal mares and aged, subfertile mares after transfer to normal recipient mares. J Reprod Fertil 85: 187-194.

62. Wilsher S, Kolling M, Allen WR (2006) The effects of oestrogen during early pregnancy in the mare on serum progestagen and IGF-1 levels and embryonic growth. Anim. Reprod. Sci. 381-382.

63. Watson ED, Nikolakopoulos E, Lawler DF (1997) Survival and normal development of an embryo after prostaglandin treatment. Equine vet. Educ. 9: 283-285.

64. Newcombe JR (2000) Spontaneous oestrous behaviour during pregnancy associated with luteal regression, ovulation and birth of a live foal in a part thoroughbred mare. Equine vet. Educ. 12: 85-87.

65. Newcombe JR (2002) Field observations on the use of a progesterone releasing intravaginal device to induce oestrus and ovulation in seasonally anoestrous mares. J. Equine Vet. Sci. 22: 378-382.

66. Stout TAE, Tremoleda JL, Knaap J, Colenbrander B (2003) Effects of treatments to prevent early pregnancy loss in the mare. 4th International Conference on Equine on Equine Reproductive Medicine. Pferdeheilkunde 19, 710.

67. Riera FL, Roldan JE, Hinrichs K (2006) Patterns of embryo recovery in mares with unilateral and bilateral double ovulations. Anim. Reprod. Sci. 94: 398-399.

68. Newcombe JR (1995) Incidence of multiple ovulation and multiple pregnancy in mares. Vet Rec 137: 121-123

69. Newcombe JR (1997) Observations on early pregnancy diagnosis and early embryonic loss in the mare. Irish Vet. J. 50: 534-536.

70. Newcombe JR, Cuervo-Arango J. (2011) Identification of the embryo proper at Days $19-22$ is a useful guide to future viability of the pregnancy. Proc Ann. Congr. British Equine Vet. Assoc. 50, 252.

71. McCue PM, Carney NJ, Hughes JP, Rivier J, Vale W (1992) Ovulation and embryo recovery rates following immunisation of mares against an inhibin alpha-subunit fragment. Theriogenology 38, 823-831.

72. Woods GL, Ginther OJ (1983) Intrauterine embryo reduction in the mare. Theriogenology 20: 699-706.

73. Woods GL, Hillman RB, Schlafer DH (1986) Recovery and evaluation of embryos from normal and infertile mares. Cornell Vet 76: 386-394.

74. Heinze H, Klug E (1975) The use of Gn-RH for controlling the oestrous cycle of the mare (preliminary report). J Reprod Fertil Suppl : 275-277.

75. Levy I, Duchamp G (2007) A single subcutaneous administration of buserelin induces ovulation in the mare: field data. Reprod Domest Anim 42: 550-554.
76. Pycock JF, Newcombe JR (1996) The effect of the gonadotrophin-releasing hormone analog, buserelin, administered in diestrus on pregnancy rates and pregnancy failure in mares. Theriogenology 46: 1097-1101.

77. Newcombe JR, Martinez TA, Peters AR (2001) The effect of the gonadotropinreleasing hormone analog, buserelin, on pregnancy rates in horse and pony mares. Theriogenology 55: 1619-1631.

78. Newcombe JR (2006) Further studies of the effect of buserelin given in dioestrus on reproductive performance. Proc. 45th Congress British Equine Vet. Assoc. 45, 211.

79. Kanitz W, Schneider F, Hoppen HO, Unger C, Nürnberg G, et al. (2007) Pregnancy rates, $\mathrm{LH}$ and progesterone concentrations in mares treated with a GnRH agonist. Anim Reprod Sci 97: 55-62.

80. Lawler DF, Pedersen HG, Watson ED (1997) Administration of buserelin to mares nine days after oestrus: Ovarian and hormonal changes. Proc 36th Ann. Congr. British Equine Vet. Assoc. p.123.

81. Stout TAE, Tremoleda JL, Knaap J, Daels P, Kindahl H, et al. (2002) Middioestrous $\mathrm{GnRH}$ analogue administration does not suppress the luteolytic mechanism in mares. Theriogenology 58: 567-570.

82. Unger C, Schneider F, Hoppen HO, Becker F, Nurnberg G, et al. (2002) Pregnancy rates in mares after application of gonadotrophin releasing hormone analogue, buserelin in warmblood mares. Theriogenology 58: 635-638.

83. Watson ED, Pedersen HG, Frazer HM (1997) Attenuation of progesterone secretion by use of a $\mathrm{GnRH}$ antagonist in the mare. Proc $36^{\text {th }}$ Ann. Cong. British Equine Vet. Assoc.

84. Benirschke K (2007) Plains Viscacha Lagostomus maximus. In: Comparative Placentation, Benirschke K. (Ed) International Veterinary Information Service, Ithaca NY

85. Ginther OJ (1985) Embryonic loss in mares: Nature of loss after experimenta induction by ovariectomy or prostaglandin $\mathrm{F}$ (2alpha). Theriogenology 24: 87 98.

86. Ginther OJ, Gastal EL, Gastal MO, Beg MA (2005) Regulation of circulating gonadotropins by the negative effects of ovarian hormones in mares. Biol Reprod 73: 315-323.

87. Reichler IM, Barth A, Piché CA, Jöchle W, Roos M, et al. (2006) Urodynamic parameters and plasma LH/FSH in spayed Beagle bitches before and 8 weeks after GnRH depot analogue treatment. Theriogenology 66: 2127-2136.

88. Neill JD, Musgrove LC, Duck LW (2004) Newly recognized GnRH receptors: function and relative role. Trends Endocrinol. Metab. 15: 383-392.

89. Sasaki K, Norwitz ER (2011) Gondotrophin-releasing hormone / gonadotrohin releasing hormone receptor signalling in the placenta. Curr. Opin. Endocrinol. Diabetes. Obes. 18: 401-408

90. Shemesh M (2001) Actions of gonadotrophins on the uterus. Reproduction 121 835-842. 